\title{
Europe's Melancholias: Diasporas in Contention and the Unravelings of the Postwar Settlement
}

\section{Eve Rosenhaft}

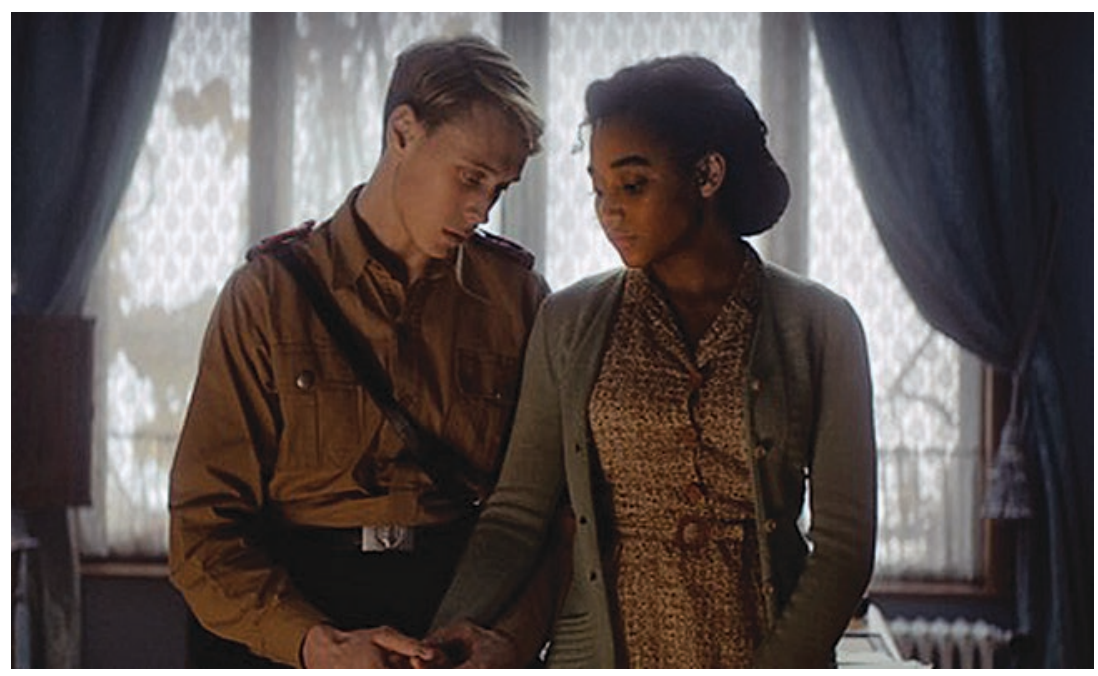

Fig. 3.1 Still from the film Where Hands Touch (Tantrum Films)

\section{E. Rosenhaft $(\bowtie)$}

School of Histories, Languages \& Cultures, University of Liverpool, Liverpool, UK e-mail: dan85@liverpool.ac.uk

(C) The Author(s) 2021

J.-H. Lim, E. Rosenhaft (eds.), Mnemonic Solidarity, Entangled Memories in the Global South, https://doi.org/10.1007/978-3-030-57669-1_3 
Abstract Rosenhaft explores some ways in which discourses of human rights, racism and antisemitism that emerged in the global North after 1945 have been appropriated, complicated and disrupted in this century's memory conflicts. She examines Black Holocaust fictions in the light of changes in the global Black diaspora, and reflects on the recent debates on antisemitism and Holocaust memory that place diasporic actors in contention as well as on the populist trope of a "white, Christian Europe". Following Paul Gilroy's use of the term "postcolonial melancholia" to characterize British nostalgia for empire, she identifies analogous forms of nostalgia driving the current memory wars, and deploys the notions of "post-Holocaust" and "post-imperial" melancholias as complementary responses to the challenges posed by the (re-)emergence of a multicultural Europe.

Keywords Holocaust memory • Black diaspora • Antisemitism • Israel - Melancholia - Multidirectional memory

This chapter reflects on the ways in which, in the twenty-first century, generational change and shifting patterns of migration and diaspora have combined to complicate and challenge the discourses of human rights, racism and antisemitism that emerged in Europe and the United States in the wake of the Second World War and the Holocaust. These discourses underpinned a structure of what Michael Rothberg called "multidirectional memory" which, fragile though it has always been, seemed for a time to promise a degree of solidarity among the victims of genocide, war and colonialism living in the global North or raised in its philosophical traditions, and reflected the hegemonic power of a vision of "human rights" allied to a politics of redress for historical wrongs. ${ }^{1}$ The twenty-first century has witnessed a falling-out among the parties to that solidarity and a renewal of memory contests, even in the liberal West. These are manifested equally in publicly debated anxieties about antisemitism that center for the first time on parties of the left, in the historical (including Holocaust) revisionism of populist and right-wing movements and governments, and in the renewal of claims of national sovereignty in opposition to human rights discourse.

\footnotetext{
${ }^{1}$ Michael Rothberg, Multidirectional Memory: Remembering the Holocaust in the Age of Decolonization (Stanford: Stanford University Press, 2009).
} 
In the European frame, an important source of antagonism is the failure of white Europe as a whole to come to terms with the legacies of colonialism-including the demographic consequences of two world wars. In the British case, Paul Gilroy has characterized the pathology of this failure in terms of "postcolonial melancholia"—a nostalgia for empire that refuses to accept its lived and living consequences in the here and now. ${ }^{2} \mathrm{I}$ want to suggest that it is possible to identify analogous forms of nostalgia driving the current memory wars, as forms of metropolitan amnesia about the character of imperial polities that manifest as melancholia come up against new claims of physical presence (diaspora) that are still realizing the implications of empire in the metropolis. This is true not only of the historical colonial metropoles of Western Europe, but also of the former continental empires of Eastern and Central Europe, and those parts of the global North that partake of the mnemospace created by the post-1945 settlement and re-molded by its collapse at the end of the 1980s-the United States and Israel. I tentatively introduce the notions of "postHolocaust" and "post-imperial" melancholia as complementary responses to the real challenges posed by the (re-)emergence of a multicultural Europe. The first result of this encounter between contending claims on the past has been rage; the question is whether it is possible to go beyond that to new forms of shared ownership of the past.

A feature of these recent developments is the mobilization of diasporic populations both in solidarity with human rights struggles abroad and in defense of "homeland" states against human rights claims. The fact of such mobilization is not new; the modern history of migration has seen many episodes in which conflicts in the homeland and the political dispositions they generate have been transposed to the new lands of settlement. And they are a reminder, among other things, of the ambivalence of the dynamic relationship between vernacular and official memory discussed in the introduction to this volume. The modes of mobilization and their consequences shift over time as the who, why and where of migration flows change along with the self-perceptions of homelands. ${ }^{3}$ The reconfiguration of diasporas leads to new kinds of conversations within and between them, all of which have a mnemonic dimension. Memory, after all, does not exist without rememberers, and memory communities are

${ }^{2}$ Paul Gilroy, Postcolonial Melancholia (New York: Columbia University Press, 2005).

${ }^{3}$ Cf Latha Varadarajan, The Domestic Abroad. Diasporas in International Relations (Oxford: Oxford University Press, 2010) and the literature cited there. 
subject to generational and demographic change. This unpicking of the materiality of cultural memory is key to understanding the prospects for mnemonic solidarity.

\section{Black Holocaust Fictions and Conversations IN THE DiASPORA}

I start by considering how the dynamics of internal contention within an evolving global diaspora are at work on the familiar territory of "multidirectional memory," namely in the imaginative engagement of contemporary Black cultural producers with the Holocaust. In his chapter in this volume, Jie-Hyun Lim sketches out a still-remembered history of shared human rights struggles between Jewish radicals and Black activists in Europe, America and Europe's settler colonies. To some extent what I call Black Holocaust fiction continues in dialogue with that history. That dialogue has taken on new dimensions in the twenty-first century, and those are the focus of the second section of this chapter. What I explore here is the consequences of the way in which the Afro-diasporic memory space is being reconfigured through the growth of an African and Afro-Caribbean immigrant population in the United States and the emergence of new "Afropean" voices. ${ }^{4}$ Those voices challenge the primacy of the transatlantic slavery narrative and its heirs in the United States.

Novels and films produced since 1999 and more particularly since the mid-2000s partake of a moment of intensification of representation of a Black Holocaust experience. This began with the increased circulation of knowledge and information about the experiences of Black people in Nazi Germany and occupied Europe, and it is notable that the three novels that interest me here, Clifford's Blues (1999) by John A. Williams, Half-Blood Blues (2011) by Esi Edugyan, and The Book of Harlan (2016) by Bernice McFadden, all include bibliographies. ${ }^{5}$ The bibliographies claim historical authenticity for their stories; they also indicate that the writers are drawing on knowledge of the persecution that was certainly intimated in the 1940s but was then largely forgotten for fifty years. In the English-speaking

${ }^{4}$ For a recent work that engages this term critically but affirmatively, see Johny Pitts, Afropean. Notes from Black Europe (Harmondsworth: Penguin, 2019).

${ }^{5}$ John A. Williams, Clifford's Blues (Minneapolis: Coffee House Press, 1999); Esi Edugyan, Half-Blood Blues (London: Serpent's Tail, 2011); Bernice L. McFadden, The Book of Harlan (New York: Akashic Books, 2016). 
world, television and the internet contributed to the dissemination and popularization of information about Black Holocaust experiences. John Williams was inspired by seeing a photograph of a Black inmate on a visit to Dachau, but Esi Edugyan was one of a younger generation who found the images that piqued their curiosity in books and on the internet. ${ }^{6}$ The first English-language television documentary on the subject, Hitler's Forgotten Victims, was made for the British broadcaster Channel 4 in 1997 (written by Cameroonian Moise Shewa and directed by Briton David Okuefuna). The year 2002 saw the publication of Clarence Lusane's Hitler's Black Victims, the first serious attempt to bring together the published evidence on the subject, and Tina Campt's Other Germans, a groundbreaking and theoretically sophisticated work on race and gender in the lives of Afro-Germans persecuted by the Nazis, came out in 2004. In 2006, Raffael Scheck published his study of the German army massacres of French colonial troops in 1940-numerically the largest group of Hitler's Black victims.?

New fictions were thus a natural response to the rhythms of public knowledge and interest, as more became knowable about the situation of Black people under Nazism. But they can also be read as reflections the contemporary Black experience. Each of the novelists chooses an AfricanAmerican man as protagonist, and each of the protagonists either finds himself in a concentration camp or narrowly escapes it after having arrived in Europe as a jazz performer. In a 2011 reflection on the memory contests triggered by the conflict in Palestine, Michael Rothberg implicitly distinguishes between memories as such and the "unavoidable building

\footnotetext{
${ }^{6}$ Gilbert H. Muller, Michael Blaine and Raymond C. Bowen, "Clifford's Blues: A Conversation with John A. Williams," in Conversations with John A. Williams, ed. Jeffrey A. Tucker (Jackson, MS: University Press of Mississippi, 2018), 217-26; Maaza Mengiste, "The Place in Between: An Interview with Esi Edugyan," Callaloo 36, no. 1 (Winter 2013): 46-51; Esi Edugyan, Dreaming of Elsewhere. Observations on Home (Edmonton: University of Alberta Press, 2014); Cath Clarke, "A secret romance: the director who is confronting Nazis, race and bigotry" (Interview with Amma Asante), The Guardian, May 3, 2019, https://www.theguardian.com/film/2019/may/03/secret-romance-ammaasante-director-nazis-race-bigotry.

${ }^{7}$ Clarence Lusane, Hitler's Black Victims. The Historical Experiences of Afro-Germans, European Blacks, Africans, and African Americans in the Nazi Era (New York: Routledge, 2002); Tina Campt, Other Germans: Black Germans and the Politics of Race, Gender, and Memory in the Third Reich (Ann Arbor: Michigan University Press, 2004); Raffael Scheck, Hitler's African Victims. The German Massacres of Black French Soldiers in 1940 (Cambridge: Cambridge University Press, 2006).
} 
blocks or morphemes of memory," adding that the fact that those morphemes are combined in multidirectional ways does not have any particular political valence. ${ }^{8}$ When the authors of Black Holocaust fictions place African-American jazzmen in Nazi concentration camps, what they are doing is to mobilize highly recognizable "morphemes" from intersecting memory traditions. The relationship between the narratives thus generated and what is known about the reality of Hitler's Black victims, however, is highly attenuated. Even in proportion to the relatively small Black presence in Germany, there were few Black people in concentration camps. Most victims were settled colonial immigrants or German-born Blacks and they suffered mainly from loss of access to education, training and work, denial of citizenship, forced labor and the threat and reality of compulsory sterilization. While each of the novels acknowledges in some degree the historical reality of Afro-German and other non-American Black victims, the African-American perspective remains central. In The Book of Harlan, the depiction of life in Buchenwald is distinguished by its deployment of an extremely sensationalized version of the concentration camp morpheme. But the concentration camp story is simply an episode, though in some senses the climax, in what is essentially a twentieth-century family saga based on the author's own family history.

I want to propose that the timing and shape of these fictions has something to do with the shifting balance between optimism and pessimism in Black memory communities. This seems to me to be particularly true of Williams and McFadden, both African Americans (Edugyan was born in Canada to Ghanaian parents). For their protagonists, Europe's jazz metropolises Berlin and Paris, which historically figured in the AfricanAmerican imagination as spaces of liberty and escape, become places of incarceration and death. In fact Clifford's Blues is modeled on a slave narrative and portrays its protagonist's survival for twelve years in Dachau as a return to slavery, in his case forced domestic service to an SS officer. ${ }^{9}$ An earlier working of the motif of return, Octavia E. Butler's 1979 Kindred, although not itself a Holocaust fiction, anticipates this. In Kindred, a twentieth-century African-American woman who finds herself repeatedly transported back to a slave plantation to ensure the survival of her white

\footnotetext{
${ }^{8}$ Michael Rothberg, "From Gaza to Warsaw: Mapping Multidirectional Memory," Criticism 53, no. 4 (2011): 523-48.

${ }^{9}$ Heidi Elisabeth Bollinger, "Crimes of Racial and Generic Mixing in John A. Williams's Clifford's Blues," Journal of Narrative Theory 44, no. 2 (2014): 267-303.
} 
great-grandfather has recourse to reading about Nazi concentration camps in her effort to understand the psychological regime of the plantation. ${ }^{10}$

The world of these novels is a world of imperiled Black bodies; their vision is a pessimistic one. The publications of the past twenty years reflect not only the availability of new materials for envisioning the Holocaust past but the present of "post-postracial America," of Black Lives Matter, of unsanctioned police killings and, most recently, the tolerated assertiveness of organized white racism in the public sphere. ${ }^{11}$ And these grounds for pessimism are not restricted to the United States. The move to the right signaled by Donald Trump's election in the United States was echoed by the outcome of the Brexit referendum in Britain and all that has followed, and indeed by the resurgence of the populist right across Europe. Literary Afro-pessimism and the Black Lives Matter movement have also become part of the German political and cultural scene. ${ }^{12}$

In Britain, Paul Gilroy's 2005 diagnosis of "postcolonial melancholia" mourned the slipping away of "the ludic, cosmopolitan energies and democratic possibilities so evident in the postcolonial metropolis" that he had identified in his earlier work. More than ludic possibilities have been lost in the succeeding decade and a half. In what has become known in the United Kingdom as the Windrush Scandal, between 2012 and 2019 a still unknown number of Black Britons were denied access to housing, jobs and healthcare and 88 were deported to countries in the Caribbean where they had been born but never lived; some died abroad, alone and in fear, while the deaths of others still in the United Kingdom were hastened by the stress of their situation. The victims of what the then Prime Minister celebrated as a "hostile environment" for illegal immigrants had arrived as children or been born in Britain between 1948 and 1973, while their parents, as colonial subjects, still carried British passports under the old imperial dispensation. Their status as British nationals was affirmed in law when immigration rules were tightened in the wake of decolonization in the

${ }^{10}$ Octavia E. Butler, Kindred (New York: Doubleday, 1979).

${ }^{11}$ For a recent use of "post-postracial," see Alison Landsberg, "Post-postracial America. On Westworld and the Smithsonian National Museum of African American History and Culture," Cultural Politics 14, no. 2 (July 2018): 198-215.

${ }^{12}$ Priscilla Layne, "The Darkening of Europe: Afrofuturist Ambitions and Afropessimist Fears in Damir Lukacevic's Dystopian Film Transfer (2010)," Seminar 55, no. 1 (February 2019): 54-75; Kevina King, "Black, People of Color and Migrant Lives Should Matter: Racial Profiling, Police Brutality and Whiteness in Germany," in Rethinking Black German Studies, eds. Tiffany N. Florvil and Vanessa D. Plumly (Oxford: Peter Lang, 2018), 169-96. 
1970s. But that status was nowhere documented, so when they were challenged to prove that they were not in the country illegally they could not. ${ }^{13}$ In effect, the system-the archive and the people whose job it was to manage the archive and the polity itself-had forgotten that they existed.

It is not surprising, then, that Black writers and filmmakers outside the United States are also producing Holocaust fictions. ${ }^{14}$ Moreover, they are deploying some of the same morphemes. But they are using them in rather different ways to place Black Europeans in Holocaust history and to reflect on the issues of race and identity particular to them. Anglophone African migrants of the second generation are notable for the interest they have shown in the Black Holocaust. As noted above, the first television documentary was made by a Black Briton. In an early short film, The Greatest Escape, Black British filmmaker John Sealey places a Tirailleur Sénégalais-a French colonial soldier-in a German POW camp to develop a surrealist riff on the still resonant statement "There are no Black Germans." The narrative moves from realistic scenes of capture and racial abuse to a comic conclusion in which the protagonist is able to leave the camp simply by putting on the commandant's coat and rebuking the sentries on his way out-certified German by the uniform and accordingly no longer Black. Sealey describes the film as a reflection on his own experience of invisibility, reinforced by observing the non-presence of Black people in Hollywood movies. ${ }^{15}$ In Canadian Esi Edugyan's Half-Blood Blues, although AfricanAmerican Sid is the protagonist-narrator, the narrative centers on his fellow bandsman Hiero, a mixed-race German, who is sent to a concentration camp as a result of Sid's actions. The year 2018 saw the release of Amma Asante's feature film Where Hands Touch. The film tells the story of Leyna, the daughter of a French colonial soldier and a German mother, who falls

\footnotetext{
${ }^{13}$ Amelia Gentleman, The Windrush Betrayal: Exposing the Hostile Environment (London: Guardian Faber, 2019).

${ }^{14}$ A non-European example with a strong European connection is the plan for a film based on the documented experiences of mixed couples in Nazi Germany under development by the Nigerian web entertainment company EbonyLife Films "AVA AND DUANTE," EbonyLife Films, accessed April 25, 2020, https://ebonylifefilms.com/filmsindevelopment/. EbonyLife's founder and CEO is Mosunmola Abudu, born in London to Nigerian parents.

${ }^{15}$ The Greatest Escape, dir. John Sealey (GB 2003); John Sealey, "Black and German: Filming Black History and Experience," in Africa in Europe. Studies in Transnational Practice in the Long Twentieth Century, eds. Eve Rosenhaft and Robbie Aitken (Liverpool: Liverpool University Press, 2013), 234-47.
} 
in love with the son of an SS-officer while evading sterilization in 1944 Berlin. Asante, raised in London by Ghanaian parents, tells a complex story about her engagement with this history: Although she has made two films which focus on global Black British history and questions of racial allegiance-Belle (2014) and A United Kingdom (2016)—Where Hands Touch was in fact her first project for a historical drama. Even as a schoolgirl she was fascinated by the Holocaust - caught up in that global circulation of threshold knowledge referred to above. But her own experience of living with outspoken racism in South London led her to want to anatomize white racism at the same time as she reflected on her own Black British identity and the meanings of belonging. ${ }^{16}$

What these cultural producers make of the Holocaust story, and the ways in which their fictions have been received, relate to shifts and asynchronies in the shape of the diaspora that is the source and audience for new historical fictions. The entry into the historical conversation of people of color who are not descendants of enslaved Africans is changing the nature of the conversation within the global Black community. If the relationship of Africans and Afropeans to the Holocaust is mediated by their own experiences of colonialism, postcolonial conflicts and migration, the same is equally true of their relationship to the historical traumas of African Americans. The American critic Michelle Wright has drawn attention to the significance of this. In her book Physics of Blackness she insists on the limitations of what she calls the Middle Passage Epistemology, which prioritizes transatlantic slavery and its narratives in the articulation of Black diasporic identity. Against this "genealogical," hierarchical and heteronormative understanding of Black identity she argues for one that acknowledges multiple origins and possible forms of affinity. ${ }^{17}$ African and Afropean writers, too, have been critical of claims, explicit and implicit, that the only historically relevant Black experience is (a particular version of) the African-American one. ${ }^{18}$

\footnotetext{
${ }^{16}$ Clarke, "A secret romance"; Amma Asante's home page: "AMMA ASANTE," accessed May 5, 2020, www.ammaasante.com.

${ }^{17}$ Michelle M. Wright, Physics of Blackness. Beyond the Middle Passage Epistemology (Minneapolis: University of Minnesota Press, 2015).

${ }^{18}$ For example, Paul Tiyambe Zeleza, "Rewriting the African Diaspora: Beyond The Black Atlantic," African Affairs 104, no. 414 (January 2005): 35-68; Aretha Phiri, "Expanding black subjectivities in Toni Morrison's Song of Solomon and Chimamanda Ngozi Adichie's Americanah," Cultural Studies 31, no. 1 (2017): 121-42.
} 
Conversely, the first reactions to the trailers for Where Hands Touch and following its release in North America reflected a significant degree of non-recognition on the part of American viewers of the particularities of the Black European experience. Among the critical responses was a combination of disgust and incredulity at the visible pairing of the AfroGerman protagonist with a boy who is not only white but wearing a Nazi uniform. Some viewers were irritated by Asante's inversion of the jazz morpheme: Here, it is the son of a white German fan of Billie Holiday who introduces Leyna to the forbidden music. ${ }^{19}$ It is important in this context that Sealey, Edugyan and Asante are all explicit about using stories which place their protagonists in conditions of extreme stress to explore questions of identity for Black people living in majority white communities (like Afropeans both before and since the Second World War), and that for Edugyan and Asante the character who articulates this problem is of mixed race: a German with an African father. It is striking, too, that all three end their narratives of radical imperilment on an optimistic note: I have noted the comic dénouement of The Greatest Escape; Half-Blood Blues ends with a reconciliation between Sid and Hiero, who has survived the camps, while Asante's Leyna survives to give birth to a mixed race child of her own.

For all their optimism these texts - and their authors-offer warnings against racism, but this generation of Afro-diasporic cultural producers has its own questions to ask of history. It is positioning itself somewhere between the undifferentiated "humanity" of global-genocide discourse with its analogies between slavery, colonialism and Holocaust and the Black Europeans who were more than accidental victims of Nazi genocide. The more immediate sense that if this is not my history, it might have been, reflects not just the emergence of a global memory space but a conviction of global citizenship that goes beyond the diasporic-and which its subjects rightly see as being under threat from the rise of new forms of populism and exclusionism.

\footnotetext{
${ }^{19}$ See Kate Erbland, “'Where Hands Touch' Filmmaker Amma Asante Responds to Claims Her WWII Drama 'Romanticizes Nazism'-TIFF,” Indiewire, September 9, 2018, https:// www.indiewire.com/2018/09/where-hands-touch-amma-asante-responds-socialmedia-1202001098/. Criticisms included observations about "taste" and the danger of humanizing the perpetrators which are familiar from generic debates about Holocaust representation.
} 


\section{Antisemitism Wars: Challenging the Authority of Holocaust Memory}

These new questions of mutual recognition within the Black diaspora are coinciding with a renewed crisis of mutual recognition between diasporic Blacks and Jews. In America, the strain of pessimism in thinking about "race" that was briefly interrupted by the "post-racial" moment with its ludic possibilities reaches back over a generation, to the disillusion that followed the murders of Martin Luther King and Malcom X, the criminalization and bloody suppression of radical Black activism and the progressive de-coupling of civil rights from social and economic justice programs in public policy. In the framing narrative of Clifford's Blues, the publisher who receives the protagonist's manuscript camp diary reflects that it is unlikely to be published because of a "severe generic problem in this business"- the problem of seeing Blacks and Holocaust in the same frame. The conjuncture of new knowledge about the Holocaust with the rise of an Afro-pessimist vision can explain the publication of Clifford's Blues in 1999 , but in fact it was written in the 1980s, and has a clear affinity with Williams' dystopian works. ${ }^{20}$ The protagonist of The Book of Harlan, having survived Buchenwald, lives through the downward spiral of urban Black communities in the 1970s and when he takes his revenge by murdering a former camp guard at the end of the novel, the redemption is a bitter one.

The moment of disappointment of the civil rights movement was also the moment of the unraveling in America of that historic alliance between Blacks and Jews, initially intensified by the Holocaust experience, that is invoked in Paul Gilroy's work of the 1990s and in Rothberg's Multidirectional Memory. ${ }^{21}$ Rothberg and Gilroy were optimistic about the possibility that those solidarities could be realized again, once the material histories of common struggles were recalled. But by that time the prospects were already poor. Williams, whose wife was Jewish, signals solidarity by introducing Clifford's Blues with lines by Aimé Césaire that

\footnotetext{
${ }^{20}$ Bollinger, "Crimes"; Anthony C. Cooke, "Black Community, Media and Intellectual Paranoia-as-Politics," Journal of Black Studies 42, no. 4 (2011): 609-26.

${ }^{21}$ Paul Gilroy, The Black Atlantic. Modernity and Double Consciousness (London: Verso, 1993); Paul Gilroy, Between Camps. Nations, Cultures and the Allure of Race (Cambridge, MA: Belknap Press, 2000); Rothberg, Multidirectional Memory. See Eric J. Sundquist, Strangers in the Land. Blacks, Jews, Post-Holocaust America (Cambridge, MA: Belknap Press, 2005 ) for an analysis of the literary manifestations of the unraveling alliance.
} 
invoke the two histories of slavery and oppression in the figure of the rivers of Babylon. But in a later interview he expressed impatience with forms of Jewish Holocaust piety that minimized the significance of the suffering of other victims. ${ }^{22}$

Claims for the primacy of Jewish victimhood gained new currency as the first decade of the twenty-first century waned. They are implicit in the ways in which Holocaust remembrance has become tied to celebration of the state of Israel in key public institutions. This nexus has been constructed over decades, but at a time when Israel was on the defensive against challenges to its moral and political legitimacy as a result of its occupation policies and domestic ethno-nationalism, its outcome was a new version of the hierarchical victim discourse that articulates moral authority in terms of Jews' privileged claim to victim status. For a period, at least, support for Israel as a principle became a precondition for moral and political legitimacy in public discourse, opening both specific criticism of Israel and talk of other victims (historical and contemporary) to charges of antisemitism.

These charges were actively deployed in political contests as the center fell away in the mid-2010s. In 2016, the British Labour Party under a new left-wing leadership became the main target of accusations of antisemitism. Challenged to resolve the problem by adopting the definition of antisemitism propagated by the International Holocaust Remembrance Alliance, the party was divided over the aspects of that definition which identify certain propositions about the state of Israel as examples of antisemitic speech. These include "denying the Jewish people their right to self-determination, e.g., by claiming that the existence of a State of Israel is a racist endeavor; applying double standards by requiring of it a behavior not expected or demanded of any other democratic nation; [and] drawing comparisons of contemporary Israeli policy to that of the Nazis" as well as "accusing Jewish citizens of being more loyal to Israel, or to the alleged priorities of Jews worldwide, than to the interests of their own nations [or] holding Jews collectively responsible for actions of the state of Israel." 23 Members of the party who, like party leader Jeremy Corbyn himself, were sympathetic to the situation of the Palestinians and critical to different degrees and in varying terms of Israeli policy perceived the terms of the

${ }^{22}$ Muller, Blaine and Bowen, "Clifford's Blues," 221.

23 "Working Definition of Antisemitism," IHRA, accessed May 5, 2020, https://www. holocaustremembrance.com/node/196. 
IHRA definition as inhibiting legitimate critical discussion of the past and present of the Middle East. The angry exchanges that ensued within the party and between the party and its critics, and which effectively set the leadership in opposition to the organized Jewish community in Britain as well as to many Jews within its own ranks, encompassed much more than the question of Israel, but the issue of mnemonic loyalty raised by the IHRA definition remained at its center. ${ }^{24}$

A particularly problematic aspect of the IHRA definition is the ban on comparisons in combination with the anticipated charge of "double standards." Implicitly reasserting the uniqueness of the Holocaust-as-Shoah, these provisions ignore the ways in which comparison between the crimes of the Nazis and other abuses, historical and contemporary, has become the currency of political rhetoric and also the object of scholarship. They also (paradoxically) limit the generalizability of the lessons of the Holocaust, which is part of the IHRA's mission. In the United States, these implications played themselves out during the summer of 2019 when Congresswoman Alexandria Ocasio-Cortez characterized the migrant detention camps on the US-Mexico border as concentration camps. ${ }^{25}$ Amid the subsequent media storm, the United States Holocaust Memorial Museum (USHMM) felt obliged to issue a statement condemning all efforts to draw historical analogies with the Holocaust. Unsurprisingly, this provoked immediate protest from several hundred scholars and memory activists. ${ }^{26}$

The implications of this moment for mnemonic solidarity across racial divides was made clear by President Trump's attacks on Ocasio-Cortez and other Democratic congresswomen of color, attacks which linked their status as racialized immigrants, their socialist politics, their championing of immigrant rights and the imputation of antisemitism into a single charge of anti-Americanism. The charge of antisemitism, which did not

${ }^{24}$ The chronicle of these debates has yet to be written. The internal inquiry which was designed to resolve the question became an object of contention itself: Shami Chakrabarti, "The Shami Chakrabarti Inquiry," accessed May 5, 2020, https://labour.org.uk/wp-content/uploads/2017/10/Chakrabarti-Inquiry-Report-30June16.pdf.

${ }^{25}$ Sheryl Gay Stolberg, "Ocasio-Cortez calls migrant detention centers 'concentration camps,' eliciting backlash," The New York Times, June 18, 2019, https://www.nytimes. $\mathrm{com} / 2019 / 06 / 18 / \mathrm{us} /$ politics/ocasio-cortez-cheney-detention-centers.html.

${ }^{26}$ Omer Bartov et al., "An Open Letter to the Director of the US Holocaust Memorial Museum." New York Review of Books, July 11, 2019, https://www.nybooks.com/ daily/2019/07/01/an-open-letter-to-the-director-of-the-holocaust-memorial-museum. 
originate with Trump but has been repeatedly deployed against them and other figures on the political and academic left, arises principally from their critique of Israeli policy, and in particular from their support for the campaign for Boycott, Disinvestment and Sanctions (BDS) against Israel. In December 2019, Trump issued an executive order which effectively redefined Judaism as a race or nationality. This made anti-Zionism (in the form of BDS) prosecutable under civil rights legislation, while at the same time declaring American Jews dual nationals with implicitly divided allegiancediasporics in spite of themselves. ${ }^{27} \mathrm{~A}$ particularly resonant example of the racial dimensions of the divide over BDS came when a civil rights organization in Alabama withdrew its offer of an award to the distinguished African-American philosopher and activist Angela Davis on the grounds of her support for BDS, apparently at the urging of a local Holocaust education group. ${ }^{28}$

Germany, too, was drawn into these "antisemitism wars" at the end of 2018. An anonymous communication to the German government, apparently of Israeli origin, accused a very large group of publicly financed NGOs of anti-Israeli bias in their support for Palestinian communities, their provision of platforms for speakers critical of Israel or their promotion of exhibitions that engage with historical and contemporary dimensions of Arab-Jewish relations in Israel. ${ }^{29}$ In the wake of a Bundestag resolution of May 2019 affirming that the BDS movement is antisemitic, the director of the Jewish Museum in Berlin was forced to resign for expressing sympathy with BDS. ${ }^{30}$ And in May 2020 several hundred writers, artists and scholars protested against the evidence that local authorities were pressuring event organizers and prize committees to withhold or withdraw awards to critics of Israeli policy. Precipitated by the anticipated "disinvitation" of Cameroonian writer Achille Mbembe by the

${ }^{27}$ Peter Baker and Maggie Haberman, "Trump targets anti-semitism and Israeli boycotts on college campuses," The New York Times, December 10, 2019, https://www.nytimes. com/2019/12/10/us/politics/trump-antisemitism-executive-order.html.

${ }^{28}$ The withdrawal was subsequently reversed: Niraj Chokshi, "Angela Davis won an award. It was revoked. Now it's been reinstated," The New York Times, January 25, 2019, https:// www.nytimes.com/2019/01/25/us/angela-davis-israel.html.

${ }^{29}$ Jannis Hagmann, “Schwere Vorwürfe aus Israel,” Die Tageszeitung, December 5, 2018 , https://taz.de/Schreiben-liegt-der-taz-exklusiv-vor/!5553564/.

${ }^{30}$ Melissa Eddy, "Director of Berlin's Jewish Museum Quits After Spat Over B.D.S.," The New York Times, June 14, 2019, https://www.nytimes.com/2019/06/14/world/europe/ berlin-jewish-museum-director-quits-bds.html. 
Ruhrtriennale, their statement cited mainly artists and scholars of color as victims of this pressure. ${ }^{31}$

The storms of 2016-2020 were manifestly precipitated by a particular geopolitical conjuncture: Under the leadership of Benjamin Netanyahu, the Israeli state, which has always been active in promoting political sympathy in the diaspora, had intensified its counter-offensive against the negative public opinion generated by its policies. This was coupled in domestic policy with the creation of "facts on the ground" through the intensification of pressure on the populations of the occupied territories, the consolidation of the permanent status of settlements in defiance of international law, and constitutional changes aimed at redefining Israel as an ethno-national state. Netanyahu's ethno-nationalism in turn made him an ally of other national populist governments, including that of Donald Trump (an affinity potentiated by the unanticipated alliance of right-wing Zionism and the Christian evangelicalism). Similarly, Germany's Christian Democrat government was on the defensive as a result of pressure from a new ethno-nationalist right whose rhetorical target was now "Islam," although it remained a source of antisemitic violence in practice.

Accordingly, these events may prove to have been a hiccup in the progress of global knowledge and understanding of the Holocaust and its lessons. Even Kenneth Stern, the author of the IHRA's working definition of antisemitism, acknowledged the specificity of the moment in December 2019: "I drafted the definition of antisemitism. Right-wing Jews are weaponizing it." ${ }^{2}$ In spite of the contretemps over historical analogies, the USHMM, like all other institutions of Holocaust commemoration and education and the global community of Holocaust scholars, continues to acknowledge the full range of victim groups under the Nazis (all concentration camp inmates and victims of genocidal bio-politics) as subjects of Holocaust. And the question of comparability continues to be explored through the critical juxtaposing of the Holocaust with other genocides, even if its epochal character remains axiomatic in the very fact and acts of commemoration.

\footnotetext{
31 "Pledge opposing ideological or political interference and litmus tests in Germany," accessed May 15, 2020, https://nopoliticallitmustests.wordpress.com/pledge-opposingideological-or-political-interference-and-litmus-tests-in-germany/.

${ }^{32}$ Kenneth Stern, "I drafted the definition of antisemitism. Right-wing Jews are weaponizing it," The Guardian, December 30, 2019, https://www.theguardian.com/commentisfree $/ 2019 / \mathrm{dec} / 13 /$ antisemitism-executive-order-trump-chilling-effect?CMP.
} 
Conversely, antisemitism is no chimera. The increase in publicly expressed hostility and violence against Jews in America and Europe is a real feature of the global rise of right-wing populism since the turn of the century. And in Britain, the harsh light shone on the Labour Party revealed that tropes and styles of thought and argument that are objectively antisemitic retain their currency and may be more easily tolerated than other forms of racism even among some who consider themselves progressive and anti-racist. ${ }^{33}$

Considered from the perspective of memory studies, though, this has something to tell us about the mutability of the meanings we attach to apperceptions of the past. Beyond opportunistic weaponizing, raising the specter of antisemitism works partly because of a real generational change in the shape of memory in the global North: Any claim to the uniqueness of the Holocaust and its message now contends with the voices of people for whom the Holocaust is not any kind of memory. In the British case, it has been argued that inattention to or trivialization of the reality and persistence of antisemitism was a consequence of the "drowning out" of postwar Holocaust consciousness after the 1960s, as racial justice was increasingly framed in terms of the claims of former colonial subjects. ${ }^{34}$ And there is force in the argument of scholars close to the Labour Party debates that routinized anti-racism can neither recognize nor counter antisemitism as long as it uncritically positions Jews as "white." ${ }^{35}$ In experiential terms, for Americans and Europeans with family histories of colonial oppression and violence, the sufferings of displaced and besieged Palestinians are more immediate than the historical trauma of Europe's Jews. And many of today's economic migrants and refugees are escaping situations in which the regional reverberations of the Arab-Israeli conflict and the great power contentions that underly it are a source of present distress. One result of this can be a lack of sensitivity to and even a new license for antisemitic language, imagery and actions in anti-imperialist and anti-capitalist discourse. Another result is that the charge of antisemitism is experienced as a silencing mechanism. In August 2018, 84 British Black and minority ethnic organizations published an open letter in which,

\footnotetext{
${ }^{33}$ Chakrabarti, Inquiry; Ben Gidley, Brian McGeever and David Feldman, "Labour and Antisemitism: a Crisis Misunderstood," The Political Quarterly, accessed May 15, 2020, https://doi.org/10.1111/1467-923X.12854.

${ }^{34}$ Andy Pearce, Holocaust Consciousness in Contemporary Britain (Oxford and New York: Routledge, 2014), 15 (citing John Solomos).

${ }^{35}$ Gidney, McGeever and Feldman, "Labour and Antisemitism."
} 
invoking common histories of colonialism and racism, they insisted that freedom to choose the terms in which they comment on Israel was indivisible from the freedom to express their own needs and call for justice as minority communities in Britain. ${ }^{36}$

In the Jewish diaspora too, and among those non-Jews for whom Holocaust memory is foundational to political identity, the passage of time has wrought changes that make for irritable responses to the claims of new diasporic actors and may block impulses to solidarity. A form of political argumentation (from either side of the debate) that declares real world solidarity with Palestinians to be incompatible with mnemonic solidarity with the victims of the Holocaust tugs at a nexus of liberal sympathies that emerged in Germany, Britain and the United States after the Second World War, though with different timing and in different forms. In Germany, whose own Jewish Holocaust survivor population is negligible, the accusation that the German government was funding antisemitic activities touched a nerve because of the West German state's long-standing commitment to both material and moral support of Israel as part of its acknowledged responsibility to the victims of the Holocaust. At the level of civil society, the accusation was directed at cultural organizations whose agenda is the promotion of intercultural dialogue and also at charities whose engagement in projects in Africa and the Middle East can be seen as part of the legacy of German colonialism. While projects of this kind remain open to the charge of neo-colonialism, they have increasingly drawn their energy from critical reflection on that history, and even before that they were part of the formation of humanitarian globalism that, along with post-Holocaust philo-Semitism, underpinned West Germany's liberal consensus. ${ }^{37}$

The counter-charge, which (even when it falls short of direct analogies between Israel and Nazi Germany) positions supporters of Israel as complicit in practices of colonialism, racism and apartheid, exposes the

\footnotetext{
36 "As BAME communities, we stand united against attempts to suppress our voices," The Independent, August 17, 2018, https://www.independent.co.uk/voices/letters/lettersihra-definition-palestine-israel-bame-sexism-labour-denmark-a8496251.html.

${ }^{37}$ Carole Fink, West Germany and Israel. Foreign Relations, Domestic Politics and the Cold War 1965-74 (Cambridge: Cambridge University Press, 2019); Britta Schilling, Postcolonial Germany. Memories of Empire in a Decolonized Nation (Oxford: Oxford University Press, 2014), 90-132; Claudia Olejniczak, Die Dritte-Welt-Bewegung in Deutschland (Wiesbaden: DUV, 1998), 75-6; Frank Stern, The Whitewashing of the Yellow Badge. Antisemitism and Philosemitism in Postwar Germany (Oxford: Pergamon, 1992).
} 
instability of multidirectional memory. But it also challenges mnemonic investment in an imagined historical moment in which global acknowledgment of the Holocaust as a Jewish catastrophe was accompanied by a consensus in the West that the historical mission of the survivors was properly embodied in the new nation-state. It is well known that that "moment" was an extended one. Even in Israel it was not until the beginning of the 1960s that there crystallized a politically potent vision of the Holocaust legacy as one that called for honoring the victims as part of the process of Jewish identity construction. ${ }^{38}$ In her chapter in this volume Carol Gluck reminds us of the importance of the 1961 Eichmann trial, which simultaneously brought the details of the Shoah to international attention and introduced Israel to the world as the champion of the survivors and other Jews in the diaspora, as well as of subsequent trials which extrapolated generic categories of crimes against humanity and commemorative justice from the Holocaust events. The adoption of the Holocaust as an identificatory point of reference for American Jews, and its entrance into the American cultural mainstream as "part of the language" (Peter Novick) was similarly the outcome of an extended chain of circumstances. ${ }^{39}$ And Britain has had its own path to "Holocaust consciousness," the identity of British Jews informed by a high degree of assimilation in spite of endemic antisemitism and a relationship with empire complicated by British policy in Palestine since the Balfour Declaration of 1917. The fact that British Jews paid a price for the ambivalence of that policy in the riots in British cities that followed incidents of Jewish terrorism Palestine in 1947 is part of a community experience that underpins their tendency to identify more strongly with Israel than other European Jewish communities. ${ }^{40}$

As different as these national contexts were, they fed into a shared imaginative nexus that tied Israel's legitimacy to its status as the guardian

\footnotetext{
${ }^{38}$ Tom Segev, The Seventh Million: The Israelis and the Holocaust, trans. Heim Watzman (New York: Holt, 2000).

${ }^{39}$ Peter Novick, The Holocaust in American Life (New York: Houghton Mifflin, 1999); Henry L. Feingold, Bearing Witness: How America and Its Jews Responded to the Holocaust (Syracuse, NY: Syracuse University Press, 1995).

${ }^{40}$ Pearce, Holocaust Consciousness; Todd Endelman, The Jews of Britain 1656-2000 (Berkeley/Los Angeles/London: University of California Press, 2002); Tony Kushner, "Anti-Semitism and austerity: the August 1947 riots in Britain," in Racial Violence in Britain 1840-1950, ed. Panikos Panayi (Leicester: Leicester University Press, 1993), 149-68.
} 
of the moral legacy of the Holocaust victims. ${ }^{41}$ That vision of Israel and a narrative of origin that underlies it was also embedded in now-canonical media representations which reached global audiences. The film Exodus, released in 1960, which depicts the struggle for the creation of a Jewish state in postwar Palestine, went beyond the novel from which it was adapted in placing Holocaust survivors in key roles as well as in its focus on the theme of their rescue. It also introduced material not present in the novel which envisioned post-liberation Israel as a nation in which Jews and Arabs could live in harmony. And its liberal credentials-sanctioned at the time by the Israeli authorities that promoted it-were sealed by the involvement of blacklisted Communists, including screenwriter Dalton Trumbo, in its production. ${ }^{42}$ The 1978 television series Holocaust, which opened a new phase in popular awareness of the Holocaust especially in West Germany, ends with the arrival in Palestine of the young German Jewish survivor Rudi. ${ }^{43}$ The closing scenes of Schindler's List (1993) make a similar mnemonic connection by taking the surviving Schindler Jews to Schindler's grave in Israel, and has clear resonances with the end of Exodus. ${ }^{44}$

As Exodus' conciliationist conclusion testifies, this vision was not at its origin the work of the political right, just as there were strong socialist and secularist elements in the Israeli nation-building project. And from this point of view it is significant that it was not only Jews on the political right whose voices were raised in alarm and accusation during the antisemitism debates of 2016-2020. In Britain, those who would not associate themselves with the politics of the right (including Jews inside the Labour

${ }^{41}$ Dan Diner, "Cumulative Contingency: Historicizing Legitimacy in Israeli Discourse," History and Memory 7, no. 1 (1995): 147-70.

${ }^{42}$ M.M. Silver, Our Exodus. Leon Uris and the Americanization of Israel's Founding Story (Detroit: Wayne State University Press, 2010); Giora Goodman, “'Operation Exodus': Israeli government involvement in the production of Otto Preminger's Film Exodus (1960)," The Journal of Israeli History 33, no. 2 (2014): 209-29. See also Alan Mintz, Popular Culture and the Shaping of Holocaust Memory in America (Seattle: University of Washington Press, 2001), 3-35.

${ }^{43}$ Holocaust (NBC, Producers Robert Berger and Herbert Brodkin, 1978). The impact of the series in West Germany was explored in a special issue of Historical Social Research/ Historische Sozialforschung 30, no. 4 (2005).

${ }^{44}$ Cf Shai Ginsburg, "An American Reflection: Steven Spielberg, The Jewish Holocaust and the Israeli-Palestinian Conflict," Miguk'ang 34, no. 1 (2011): 45-76. Ginsburg proposes that these scenes in fact reflect Spielberg's skepticism about the failure of post-1967 Israel to fulfill the Exodus vision. 
Party) were among the most sensitive to intimations of antisemitism associated with criticism of Israel and most militant in challenging them. This is in spite of the fact that while antisemitic speech and action by the nonestablishment right were certainly increasing there, there was no evidence (by comparison with the United States) of its being endorsed by government, and surveys earlier in the decade showed that British Jews suffered less from antisemitic violence and were less afraid of it than Jews elsewhere in Europe. ${ }^{45}$ Adapting Gilroy's language, I would suggest that among some diasporic Jews anxieties about antisemitism are fuelled by a postHolocaust melancholia that draws on nostalgia for that moment which they remember as endowing Israel with the moral authority to act as a beacon for postwar moral reconstruction.

\section{Populations in Motion and the Unraveling of the Postwar Settlement: Defending "White Christian Europe"}

Paul Gilroy is not the only critic to have anatomized the aporias of memory in Europe. Writing about France's memory culture, Ann Laura Stoler used the term "aphasia" to characterize the crippling incapacity of the postcolonial metropole to speak its past to itself. ${ }^{46}$ In the Western cultural and medical tradition, melancholia and aphasia are pathologies. But in invoking these terms here is not my intention to pathologize the rememberers. The point, rather, is to pose the question (implicit in the term "aphasia") of what has remained unremembered, misremembered or actively suppressed in the mnemonic construction of an identificatory moment. This should make us attentive (with Gilroy) to the losses that have been incurred in this process - what we have to mourn and who is doing the mourning. Here it helps to take into account the ways in which remembered moments decay and are reconstructed as memory

\footnotetext{
${ }^{45}$ EU Agency for Fundamental Human Rights, Experiences and perceptions of antisemitism Second survey on discrimination and hate crime against Jews in the EU (Luxembourg: Publications Office of the European Union, 2018). Cf L. D. Staetsky and Jonathan Boyd, The Exceptional Case? Perceptions and experiences of antisemitism among Jews in the United Kingdom (London: Institute for Jewish Policy Research, 2014).

${ }^{46}$ Ann Laura Stoler, "Colonial Aphasia. Race and Disabled Histories in France," Public Culture 23, no. 1 (Winter 2011): 121-56.
} 
communities are reshaped through the intervention of new rememberers-and also in resistance to those interventions.

In the case of the "antisemitism wars" the key driver at the level of mnemonic discourse is the global articulation of memories of the Nakba in forms that powerfully challenge the foundational myths of the state of Israel, which now include the Holocaust. That the challenge to Israel's current practices is often posed in the moral and rhetorical terms set in motion by the Holocaust and its aftermath appears paradoxical but is a logical consequence of that form of legitimation. But the historical moment in which the Arab-Israeli conflict emerged was the moment of a global postwar settlement, other aspects of whose legacy and memory are also now objects of contention. In 1947, India and Pakistan gained their independence. The year 1948 witnessed the United Nations Genocide Convention, which signaled the codification of a globally binding discourse of human rights in a self-conscious drawing of the lessons of the Holocaust. ${ }^{47}$ It was also the year of (among other things) the Berlin conflict which initiated the division of Germany and with it the consolidation of the Cold War in Europe and of Communist hegemony in Eastern Europe, and (with the launch of the National Health Service) the beginning of Britain's experiment in social democracy. The ambivalences of that historical moment are many, but it resulted in a relatively stable discursive framework in which states and civil society groups deployed a shared language of internationalism, rights and justice. The rise of ethno-nationalism in Europe, America and Asia has been accompanied by an explicit rejection of that language along with the institutions that the postwar world community built to realize its promise.

In this volume, Jie-Hyun Lim points to the way in which official memory cultures were also stabilized, or frozen, in that postwar consensus, when he describes how new national victimhood narratives were "released" by the ending of the Cold War around 1990. He also alludes to the fact that in Europe-as in the Indian sub-continent and in Palestine-that postwar settlement rested on policies of partition and the forced displacement of populations (indeed, of re-settlement). The case of the expulsion of ethnic Germans from Eastern Europe to which Lim refers is exemplary in the way the vernacular memory of the events was alternately

\footnotetext{
${ }^{47}$ Samuel Moyn points out that the common view that "human rights" was a product of the postwar, post-Holocaust moment is itself a retrospective construct: The Last Utopia. Human Rights in History (Cambridge, MA and London: Harvard University Press, 2010).
} 
instrumentalized and suppressed as the West German state negotiated its own relationship to the wartime and Holocaust past, to emerge after unification as part of a new narrative of German victimhood. But attention to this local example can distract from the ways in which traumas of this kind were experienced at the same time in many parts of Europe and its former colonies. We are reminded of this not least by the latest re-emergence of sources of conflict which partition and resettlement were intended to suppress, provoked and exploited by nationalist politicians who rely on selective memory and the mobilization of diasporic allegiance to legitimate their politics, whether in the Middle East or in the India of Narendra Modi. ${ }^{48}$ (The case of Britain's welfare state is a reminder that postwar reconstruction also depended on large-scale labor migration, much of it from the colonies, which, like the "Windrush generation," is itself the object of complex practices of memory and forgetting.)

It is this aspect of the way the mnemonic nexus between colonialism, imperialism and the legacies of war and Holocaust is playing out in contemporary political contests that I want to address briefly here. I focus on Eastern European reactions to the twenty-first-century "refugee crisis" and the arrival in Europe of a new generation of displaced people. What is being remembered, what forgotten? Jie-Hyun Lim's account of Polish debates suggests that in the latest round of memory contests the Holocaust may be being displaced by colonialism as the hegemonic point of reference for victimhood claims: Poles not only disavow their own historical implication in colonialist practices when they declare dark-skinned refugees to be inherently alien to the Polish body politic, but they also claim moral authority as victims of great power colonialism.

Something else that has been officially forgotten in Eastern and Central Europe is the region's long history of ethnic and religious pluralism. The cohabitation of Muslims, Christians and Jews, Slavs, Italians, Magyars, Germans and Roma, in different combinations and often in the same communities, was a feature of this part of Europe before the First World War. Politically, it was institutionalized in the constitution of the Habsburg Empire, and the cosmopolitanism fostered, celebrated and constantly

\footnotetext{
${ }^{48}$ On the construction and mobilization of the "global Indian," see Varadarajan, The Domestic Abroad, 107-41. On the impacts of mobilization on South Asian communities and politics in Britain: Haroon Siddique, "'Divisive Tactics'," The Guardian, November 8, 2019, https://www.theguardian.com/politics/2019/nov/08/british-hindus-urged-whats app-messages-vote-against-labour.
} 
re-negotiated by the institutions of empire survived in the successor states after its breakup. As Lim suggests, there were always hierarchical relationships and embedded practices of othering among ethnic and national groups, whether in partitioned Poland or the Habsburg Empire. And the record of irridentism, antisemitism and complicity with genocide in the states created by the 1919 peace treaties is nothing to celebrate ${ }^{49}$ In a very real sense, though, it was the Holocaust and the postwar settlement that produced ethnic homogeneity in the region.

There is thus a very particular mnemonic maneuver at work when nationalists in Poland, Hungary and Czechia invoke homogeneity as their natural heritage to legitimate their resistance to accepting refugees. In the rhetoric of Hungary's Fidesz government under Viktor Orbán, that resistance takes more militant form, as the closure of Hungary's borders to refugees is articulated as the front-line defense of a "white Christian Europe" against the invasion of an alien (i.e. Muslim) civilization. This structure of argument does have an authentic history, though it obfuscates the fact that Hungary was Europe's northernmost zone of contact with Islam and a conduit for Islamic culture until the late seventeenth century. Paired with the rhetoric of domestic defense against Jewish power, resurrected in Fidesz campaigns against George Soros and Western liberalism, it is part of the tradition of the Hungarian right, including the interwar antisemites whose legacy is being rehabilitated.

But in Hungary, returning to this interwar rhetoric means reaching back over genuinely formative (and traumatic) experiences of war, Holocaust and socialist reconstruction. And it is not accidental, but belongs to an extremely aggressive memory politics which is in some senses a study in paradoxes. ${ }^{50}$ A central paradox is the elevation of the Treaty of Trianon to the status of foundational trauma, given that, following the principle of national self-determination, the treaty both established

${ }^{49}$ Johannes Feichtinger and Gary B. Cohen, eds., Understanding Multiculturalism: The Habsburg Central European Experience (New York and Oxford: Berghahn, 2015); Omer Bartov and Eric D. Weitz, eds., Shatterzone of Empires. Coexistence and Violence in the German, Habsburg, Russian, and Ottoman Borderlands (Bloomington and Indianapolis: Indiana University Press, 2013).

${ }^{50}$ Éva Kovács, "Overcoming History through Trauma: The Hungarian Historikerstreit," European Review 24, no. 4 (October 2016): 523-34. This website presents Trianon as a "grass-roots" movement with multiple local monuments: "Nekünk még legalább két-három Trianon kéne, de hamar!” Szily László, accessed May 7, 2020, https://cink.hu/ nekunk-meg-legalabb-ket-harom-trianon-kene-de-hamar-1478546158. 
Hungary as a nation state and made it more nearly ethnically homogeneous. What is mourned, of course, is the loss of territory which created Hungarian minorities in other successor states, and which went along with the loss of the dominion over other nationalities that Hungarians enjoyed as part of the dual monarchy. From this point of view, we might characterize the Eastern European rejection of cohabitation with refugees as an expression of (late) post-imperial melancholia: It reflects a selective memory of the historical past which is re-constituting the subjects of that history as an exclusive (memory) community and thereby blocking the possibility of solidarity — or even dialogue—among its heirs.

\section{Conclusion: Memory Matters}

Memory matters. Talking about the past is an eminently political act, and talking and writing critically about how people talk about the past engages our political instincts as well as the sinews of scholarship. This incurs hazards. The present volume would have included a fifth substantive chapter, had its author not been put in danger by police action against a memory activist whose work the chapter gestured at. The challenge at the level of scholarship is that the sense of the moment that makes particular memories matter, and the equally intuitive sense of how particular articulations of memory are working in the moment, may outrun the tools of scholarship: the sources, rhythms of critical reflection and structures of explanation that normally define our disciplines. To insist on the multidisciplinarity of memory studies is to acknowledge some of the tensions between the different ways in which we address "memory," between randomness and system, allusion and analysis, topography and explanation. As a historian, I feel some discomfort when I find myself making large statements in a small space and in discursive registers that may appear incommensurate, as I have here. It incurs an obligation to explain myself and to reflect on how to take critical analysis and praxis further.

The view that scholars are called on to respond to a general crisis of democratic values and practices as the second decade of the twenty-first century begins is widespread in memory studies as in the humanities more generally. My own sense of the moment and its implications for historical memory in Europe was galvanized by my experiences in the summer of 2018, during the first engagements of what I refer here to as the 
antisemitism wars. I felt its force in the course of my own memory work in Liverpool, a proudly multicultural city with strong and fiercely politicized memory cultures, when I was party to two accusations of antisemitism. The first was directed at me. I had curated an exhibition on the persecution of German Sinti and Roma, and wanted to follow it up with an event about the rather different experience of Romanian Roma which would provide an opportunity for dialogue between Jewish survivors and their children and immigrant Roma. The use of the term "Holocaust" to characterize the genocide of Roma and Sinti in the publicity for the event led to protest from a member of the host organization. The protest asserted the historical and moral uniqueness of the Shoah; the social media context in which it was raised situated it in the militant campaign against antisemitism.

In the second case I was made aware of an accusation of antisemitism leveled against an exhibition co-curated by a colleague. The exhibition's central theme was the historical relationship between transatlantic slavery, colonialism and luxury consumption-issues central to Liverpool's civic memory politics which have also engaged my scholarly attention. All of the works on display were by British artists the Singh Twins. The image that attracted the charge of antisemitism was one displayed to complement the main exhibition. Entitled Partition Politics-Business as Usual, it offers a conspectus of partitions carried out by colonial powers, exploited by international capital, and contested by non-state actors. Images of the occupied West Bank are at the center of a design that also refers to the Scramble for Africa, the partition of India and the Western intervention in Suez, foregrounding the international arms trade as driver and beneficiary of regional conflicts. After taking advice, the gallery managers rejected the claim of antisemitism. However, while the picture remained, the gallery felt obliged to post a disclaimer at the exhibition entrance. ${ }^{51}$

In that moment the unanticipated resonances of my public engagement with the Holocaust's "other victims" encroached on my more scholarly project of the moment: puzzling out the meanings of Black Holocaust fictions. I was positioned in spite of myself in a memory war. I originally entitled this chapter "Mnemonic Knots," a pessimistic riff on

\footnotetext{
${ }^{51}$ The image is reproduced in Eve Rosenhaft, "Europe's Melancholias and the Crisis of Multidirectional Memory," global-e 12, no. 8 (2019), accessed May 15, 2020, https:// www.2 lglobal.ucsb.edu/global-e/february-2019/europe-s-melancholias-and-crisismultidirectional-memory.
} 
the notion of "entangled memories." Here, I have focused largely on the skeptical dimension of the mnemonic solidarity project, mapping a form of internal "re-territorialization" of memory. This process has manifestly been promoted and energized by the rise of the political right across the globe. But the affective power of these interventions and the discourses they have released invites us to ask how the identities of the contending groups are invested in the ways in which the past is remembered. Here, I suggest that attention to the nexus of Holocaust and postwar reconstruction as an object of both remembering and forgetting can be productive, given that it is the discourses of human rights and internationalism that emerged out of that moment that are under attack in this century. The double-edged character of the mnemonic moment is apparent in the deployment of accusations of antisemitism that draw their authority from Holocaust memory by the very politicians who are challenging the postwar settlement and promoting active racism and antisemitism at home. And the anxieties precipitated by these destabilizing contradictions are real, particularly, I argue, for those who were shaped in one way or another by the postwar moment (among whom I count myself). This is where the different subject positions (and histories) represented by dwellers in the global North become relevant, and I suggest that the effects of both migration and generational change are at work in the fracturing and reconfiguring of memory communities, both national and global-diasporic. These remain intuitions and hypotheses that invite further exploration.

Such exploration would also need to take account the epochal shifts in the political economy of the global North that have taken place since 1945 (and that have also impacted the global South). The postwar social settlement was unraveling in the West well before the collapse of socialism in the East, to be replaced by neo-liberal regimes of varying reach and intensity. From this point of view, the celebration of Britain's National Health Service - in the costumes and imagery of 1948 - that formed the centerpiece of the opening of the 2012 Olympic Games in London is no less surprising in its timing than Orbán's mourning of Trianon. It is perfectly clear that in both the East and the West of the global North, populism and xenophobia reflect the hurts incurred by neo-liberal economic policies. Less clear is how the ways in which people refer to the past in interpreting those hurts have been shaped by the dynamics of the economic system. One result of the collapse of socialism and the triumph of neo-liberalism 
was the de-legitimizing of the labor movement and its memories, and this may have contributed to the framing of Holocaust in terms that valorize victimhood. Reflecting on the dialectics of race and diaspora, critics of the paradigm of multiculturalism have pointed to the roots in consumerist individualism - the neo-liberal personality—which it shares with certain kinds of identity politics that are in permanent tension with a progressive politics of memory and practical solidarity. ${ }^{52}$ This essay has focused on imagined pasts. A further thinking through of the present mnemonic moment would need to take into account the impact of profound changes at the level of political economy, not only on structures of sentiment and expectation but also on the communicability of material pasts-experiences and aspirations.

There is, of course, a note of pessimism in my use of the term "melancholia" to denote some ways in which the selective memory of a complex history impinges on perceptions and action in the present. With Paul Gilroy, I apply it to histories that have made the global North what it is: colonialism, continental imperialism and the Holocaust foundations of both human rights discourse and the statehood of Israel. I use it not in an accusatory spirit, but to signal the tenderness of memory that makes it susceptible to shock and pain when other people's experiences of the shared past insist on being heard.

This is where the optimistic dimension of the mnemonic solidarity project comes in. The encounter between Jewish and Roma survivors that I was organizing in the summer of 2018 went ahead (with re-worded publicity) and led to a powerful exchange, new kinds of mutual recognition and continuing collaborations. In the context of my exhibition work, too, I have learned the importance of face-to-face encounters. Conversations with and between Jewish and Roma Holocaust survivors- too often contenders in a hierarchy of victimhood-confirm the potential of vernacular memory for generosity. But my exhibition experience has also taught me how important it is that those conversations are informed by a shared store of knowledge about each others' history, a level plane of understanding that enables recognition and the negotiation of difference. ${ }^{53}$ Providing

\footnotetext{
${ }^{52}$ See, for example, Rey Chow, The Protestant Ethnic and the Spirit of Capitalism (New York: Columbia University Press, 2002), 102-18. I am grateful to Ian Gwinn for provoking me to these reflections.

${ }^{53}$ Kyu Dong Lee and Eve Rosenhaft, "Roma/Holocaust/Representation. Exhibition Experiences on Two Continents," Critical Romani Studies, forthcoming 2021.
} 
that information and ensuring that it is received is one of the jobs of scholars. Scholarship and activism together will do best to link such grass roots conversations to critiques of the discourses of national and community ressentiment that constrain empathy and the social and geopolitical practices of power that persistently force us into adversarial positions"partition politics" in the widest sense.

Open Access This chapter is licensed under the terms of the Creative Commons Attribution 4.0 International License (http://creativecommons.org/licenses/ by $/ 4.0 /$ ), which permits use, sharing, adaptation, distribution and reproduction in any medium or format, as long as you give appropriate credit to the original author(s) and the source, provide a link to the Creative Commons licence and indicate if changes were made.

The images or other third party material in this chapter are included in the chapter's Creative Commons licence, unless indicated otherwise in a credit line to the material. If material is not included in the chapter's Creative Commons licence and your intended use is not permitted by statutory regulation or exceeds the permitted use, you will need to obtain permission directly from the copyright holder.

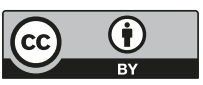

